University of Nebraska - Lincoln

DigitalCommons@University of Nebraska - Lincoln

Nebraska Cooperative Fish \& Wildlife Research Nebraska Cooperative Fish \& Wildlife Research Unit -- Staff Publications

2011

\title{
Woody Invasions of Urban Trails and the Changing Face of Urban Forests in the Great Plains, USA
}

\author{
Kristine T. Nemec \\ University of Nebraska-Lincoln, kristine.nemec@huskers.unl.edu \\ Craig R. Allen \\ University of Nebraska-Lincoln, callen3@unl.edu \\ Aaron L. Alai \\ University of Nebraska-Lincoln, aalai2@unl.edu \\ Gregory M. Clements \\ University of Nebraska-Lincoln, gclements2@unl.edu \\ Andrew C. Kessler \\ University of Nebraska-Lincoln \\ See next page for additional authors
}

Follow this and additional works at: https://digitalcommons.unl.edu/ncfwrustaff

Part of the Other Environmental Sciences Commons

Nemec, Kristine T.; Allen, Craig R.; Alai, Aaron L.; Clements, Gregory M.; Kessler, Andrew C.; Kinsell, Travis C.; Major, Annabel; and Stephen, Bruce J., "Woody Invasions of Urban Trails and the Changing Face of Urban Forests in the Great Plains, USA" (2011). Nebraska Cooperative Fish \& Wildlife Research Unit -- Staff Publications. 103.

https://digitalcommons.unl.edu/ncfwrustaff/103

This Article is brought to you for free and open access by the Nebraska Cooperative Fish \& Wildlife Research Unit at DigitalCommons@University of Nebraska - Lincoln. It has been accepted for inclusion in Nebraska Cooperative Fish \& Wildlife Research Unit -- Staff Publications by an authorized administrator of DigitalCommons@University of Nebraska - Lincoln. 


\section{Authors}

Kristine T. Nemec, Craig R. Allen, Aaron L. Alai, Gregory M. Clements, Andrew C. Kessler, Travis C. Kinsell, Annabel Major, and Bruce J. Stephen 


\title{
Woody Invasions of Urban Trails and the Changing Face of Urban Forests in the Great Plains, USA
}

\author{
KRISTINE T. NEMEC ${ }^{1}$ \\ Nebraska Cooperative Fish and Wildlife Research Unit, School of Natural Resources, 422 Hardin Hall, \\ 3310 Holdrege Street, University of Nebraska, Lincoln 68583
}

CRAIG R. ALLEN

USGS-Nebraska Cooperative Fish and Wildlife Research Unit, School of Natural Resources, 422 Hardin Hall, 3310 Holdrege Street, University of Nebraska, Lincoln 68583

AARON ALAI

Nebraska Cooperative Fish and Wildlife Research Unit, School of Natural Resources, 422 Hardin Hall, 3310 Holdrege Street, University of Nebraska, Lincoln 68583

AND

GREG CLEMENTS, ANDREW C. KESSLER, TRAVIS KINSELL, ANNABEL MAJOR AND BRUCE J. STEPHEN

School of Natural Resources, Hardin Hall, 3310 Holdrege Street, University of Nebraska, Lincoln 68583

\begin{abstract}
Corridors such as roads and trails can facilitate invasions by non-native plant species. The open, disturbed habitat associated with corridors provides favorable growing conditions for many non-native plant species. Bike trails are a corridor system common to many urban areas that have not been studied for their potential role in plant invasions. We sampled five linear segments of urban forest along bike trails in Lincoln, Nebraska to assess the invasion of woody non-native species relative to corridors and to assess the composition of these urban forests. The most abundant plant species were generally native species, but five non-native species were also present: white mulberry (Morus alba), common buckthorn (Rhamnus cathartica), tree-of-heaven (Ailanthus altissima), honeysuckle (Lonicera spp.) and elm (Ulmus spp.). The distribution of two of the woody species sampled, common buckthorn and honeysuckle, significantly decreased with increasing distance from a source patch of vegetation $(\mathrm{P}=0.031$ and 0.030$)$. These linear habitats are being invaded by non-native tree and shrub species, which may change the structure of these urban forest corridors. If nonnative woody plant species become abundant in the future, they may homogenize the plant community and reduce native biodiversity in these areas.
\end{abstract}

\section{INTRODUCTION}

Urban forests are comprised of the trees that naturally occur within remnant forests and the trees planted along streets and within yards and parks (McBride and Jacobs, 1976; McPherson et al., 1997). These patches of vegetation within a landscape dominated by concrete provide a variety of benefits to their residents and to wildlife. They remove air pollutants, store carbon, lower summer temperatures and allow people to interact with nature (McPherson et al., 1997; Bolund and Hunhammar, 1999; Chen and Jim, 2008). They also provide habitat for some birds that have adapted to urban settings (Savard et al., 2000), particularly seed eaters, omnivores, ground foragers and raptors (Chace and Walsh, 2006).

\footnotetext{
${ }^{1}$ Corresponding author: e-mail: kristine.nemec@huskers.unl.edu
} 
However, the properties of forests, including urban forests, can be affected by the invasion of non-native plant species (Martin, 1999; Vidra et al., 2006; Shustack et al., 2009). The invasion of ecosystems by non-native plants is one of the leading threats to biodiversity and can alter ecosystem structure and function (Vitousek et al., 1987; Braithwaite et al., 1989; Walker and Smith, 1997; Yurkonis et al., 2005). For example, non-native woody plants can increase decomposition rates, alter nitrogen cycling and increase soil moisture and $\mathrm{pH}$ within forests (Kourtev et al., 1999; Ehrenfeld et al., 2001; Ashton et al., 2005), which may provide a positive feedback loop by facilitating the establishment of quickly growing invasive species compared to slower growing native species (Dukes and Mooney, 1999; Gurevitch et al., 2008). Non-native trees and shrubs can decrease native plant species richness, abundance and density (Collier et al., 2002) and inhibit the growth of native saplings and forbs (Fagan and Peart, 2004; Miller and Gorchov, 2004; Galbraith-Kent and Handel, 2008).

Non-native vegetation can also impact forest fauna. The non-native shrubs European buckthorn (Rhamnus cathartica) and Japanese barberry (Berberis thunbergii) have been associated with high populations of non-native earthworms in woodlands (Kourtev et al., 1998; Heneghan et al., 2007), which can alter nutrient storage and availability, affecting soil food webs and understory plant communities (Gundale, 2002; Bohlen et al., 2004). Nonnative shrubs can decrease nest success for birds, which may be attributed to structural differences between the non-native and native shrubs which may increase predation risk (Schmidt and Whelan, 1999; Borgmann and Rodewald, 2004).

Plant invasions may be facilitated by human activities that result in habitat fragmentation. Habitat fragmentation alters the microclimate along the boundary between fragments of vegetation and their surrounding habitat (Collinge, 1996) and provides more opportunities for invasive species to become established and invade fragments (Honnay et al., 2002; Yates et al., 2004). For example, the construction of man-made corridors such as roads and trails disturbs ecosystems by baring soil, removing natural vegetation, increasing the amount of light in an area and changing drainage patterns (Dickens et al., 2005; Christen and Matlack, 2006). The disturbed habitats associated with roads and trails may encourage colonization of invasive species, which are often adapted to disturbance (Hobbs and Huenneke, 1992; Pauchard and Alaback, 2006; Flory and Clay, 2009).

Roadsides and trails differ from natural disturbances because of their linear structure (Forman et al., 2003). Species can spread long distances along the linear, continuous habitat provided by roads and trails without encountering barriers to dispersal or establishment (Christen and Matlack, 2006). Trail systems, with their many intersecting linear paths, form networks along which species can travel (Benninger-Truax et al., 1992). Roadsides and trails may further facilitate invasion by acting as movement corridors, aiding dispersal when humans carry seeds on equipment and clothing (Dickens et al., 2005) and birds transport seeds (Bas et al., 2006).

Since the 1960s, hundreds of communities in the United States have developed urban recreational trails, with many of these trails being located on former railway beds (Searns, 1995). In Lincoln, Nebraska, for example, $206 \mathrm{~km}$ of recreational trails have been created (Great Plains Trails Network, 2010). Like other linear, man-made corridors such as roads and recreational trails in natural areas (Benninger-Truax et al., 1992; Dickens et al., 2005; Potito and Beatty, 2005; Christen and Matlack, 2006), urban recreational trails may facilitate invasion by invasive plant species. Our objective was to assess the woody plant species composition of forest corridors along recreational trails in Lincoln, Nebraska, which could indicate whether bike trails served as dispersal routes for non-native tree and shrub species. If trails are effective dispersal routes for non-native species, we would expect to see non- 
native species decrease in abundance between the edge of a forest corridor and the interior of a forest corridor that serves as a source patch of invasive species along the trail.

\section{Methods \\ STUDY AREA}

This study was conducted within the city limits of Lincoln, Nebraska $\left(40^{\circ} 48^{\prime} \mathrm{N}, 96^{\circ} 40^{\prime} \mathrm{W}\right)$. Lincoln is $194.3 \mathrm{~km}^{2}$ in area and has a population of 241,200 individuals according to the 2006 U.S. Census. The city has a continental climate with a mean annual temperature of 10.6 C, a mean annual precipitation of 72.1 centimeters and 161 frost-free days (High Plains Regional Climate Center, 2010). Floodplain soils within Lincoln are moderately well drained to poorly drained, silty soils that formed in alluvium (Brown et al., 1980). Upland soils are moderately well drained or well drained, loamy or clayey soils that formed in glacial till covered by silty soils that formed in loess (Brown et al., 1980).

Historically, most of eastern Nebraska was covered with tallgrass prairie, with some small patches of trees or shrubs growing in uplands only within protected areas (Weaver, 1965). Trees and shrubs that were adapted to drier conditions included bur oak (Quercus macrocarpa), bitternut hickory (Carya cordiformis), smooth sumac (Rhus glabra) and wolfberry (Symphoricarpos occidentalis) (Weaver, 1965). Most trees grew in narrow bands of forest along creeks or streams (Weaver, 1960, 1965). Common tree species along waterways included willow (Salix sp.), cottonwood (Populus deltoides), American elm (Ulmus americana), slippery elm (Ulmus fulva), boxelder (Acer negundo), green ash (Fraxinus pennsylvanica), white ash (Fraxinus americana), chokecherry (Padus virginiana), hackberry (Celtis occidentalis) and Kentucky coffeetree (Gymnocladus dioica) (Weaver, 1960, 1965). Early accounts of the area that became Lincoln describe the landscape as prairie and largely treeless, with the exception of cottonwood, willow, honey locust (Gleditsia triacanthos), boxelder, walnut (Juglans nigra), ash and elm trees growing along local creeks such as Salt Creek and its tributaries (Burgess and Worthen, 1916; Copple, 1959).

Since the establishment of Lincoln in 1867, residents have planted trees and transformed the community into a "city of trees," some of which were transplanted from the borders of local creeks (Lincoln Chamber of Commerce, 1923). Current patches of forest vegetation within the city may represent remnants of natural forest or the expansion of trees and shrubs that have been planted. These areas are connected by Lincoln's trail system, which was largely built since the late 1980s (City of Lincoln, 1992; Great Plains Trail Network, 2010) and crosses through a mosaic of suburbs, manicured parks and herbaceous or forest vegetation. The city's current vegetation, therefore, occurs within a social-ecological system that is heavily shaped by humans. Because residents have suppressed fire and eliminated grazing, the two disturbances that limited the growth of woody vegetation and maintained the prairie ecosystem, trees and shrubs have expanded into upland areas that were formerly prairie. Non-native tree and shrub species have also been introduced to the area from street and residential plantings. Urban environments have altered hydrology, soil processes, nutrient cycling and temperature patterns compared to less developed areas (McDonnell and Pickett, 1990; Alberti and Marzluff, 2004). These urban forests, therefore, represent a novel ecosystem composed of new species compositions and new abiotic conditions relative to historic conditions within the Lincoln area (Hobbs et al., 2006).

The narrow, limited amount of green space along the trails, social opposition to prescribed fires within an urban landscape and altered abiotic environment makes restoration of the historic functioning prairie ecosystem within the city of Lincoln difficult 
if not impossible. Much of the trailside vegetation will likely continue to be maintained as urban forest into the future.

Management of the vegetation along trails that do not run through maintained parks is minimal (T. Genrich, City of Lincoln, pers. comm.). If a trail is located on a former railroad bed or another less maintained area than a park, the City of Lincoln Parks and Recreation Department will mow up to $1.5 \mathrm{~m}$ on either side of the trail every two weeks during the growing season (T. Genrich, City of Lincoln, pers. comm.).

\section{SAMPLING METHODS}

Sampling sites were chosen from aerial imagery of Lincoln identifying forest corridors that: (1) were located along paved bike trails, (2) were a minimum of approximately $200 \mathrm{~m}$ in length, (3) consisted mostly of woody vegetation and that (4) originated from a larger patch of predominantly native vegetation which we considered potential source patches from which woody vegetation has expanded because of fire suppression (Figs. 1, 2, Table 1). Five corridors that met our criteria were sampled in Mar. and Apr. 2008. Each of the five forest corridors sampled only had one source patch and the corridor was at least $0.50 \mathrm{~km}$ away from any other large patch of woody vegetation. These areas were surveyed in the natural vegetation adjacent to trails, at $30-\mathrm{m}$ intervals.

Survey points were located midway through the forest corridor and were surveyed using the point quarter method (Brower et al., 1997). If forested vegetation was located along both sides of the path, the corresponding midway point on each side of the path was surveyed. The tree or shrub species closest to the midway point in each of the four cardinal directions was recorded, as well as the diameter or circumference of the tree or shrub and the distance from the midway point to the tree or shrub. Only woody species that were living and greater than 0.6 meters in height were recorded. The trail was always sampled at $30-\mathrm{m}$ intervals whether there was forested vegetation on one side of the trail or both sides of the trail. Data for between 10 and 19 points were recorded at each site, for a total of 73 points. The number of points varied because the distance of paths with adjacent 'natural' vegetation varied.

\section{DATA ANALYSIS}

The importance value for each tree or shrub species recorded at a site was calculated by summing the relative density, relative frequency and relative coverage (Brower et al., 1997). We conducted linear regressions of individual species abundance and overall native and non-native species richness with distance from assumed source patch to test for a corridor effect along bike paths. Our data met normality assumptions according to the KolmogorovSmirnov test. The simple nonlinear regressions that we tested explained less of the variance in our data than simple linear regressions. Data analysis was conducted using SigmaStat.

\section{RESULTS}

Nineteen woody species were recorded from the forest corridors, of which two, hackberry and ash, were recorded at all five sites (Table 2). Hackberry was the most widely distributed of the observed species, found at 42 of the 73 points, and had the highest importance value at sites 2, 3 and 5 (Table 3). Silver maple had the highest importance value at site 1 and cottonwood had the highest importance value at site 4 .

Five of the species recorded at the sites, common buckthorn, tree-of-heaven, white mulberry, honeysuckle and elm were non-native. We consider the honeysuckle and elm samples to be non-native because they were primarily Amur honeysuckle (Lonicera maackii) 


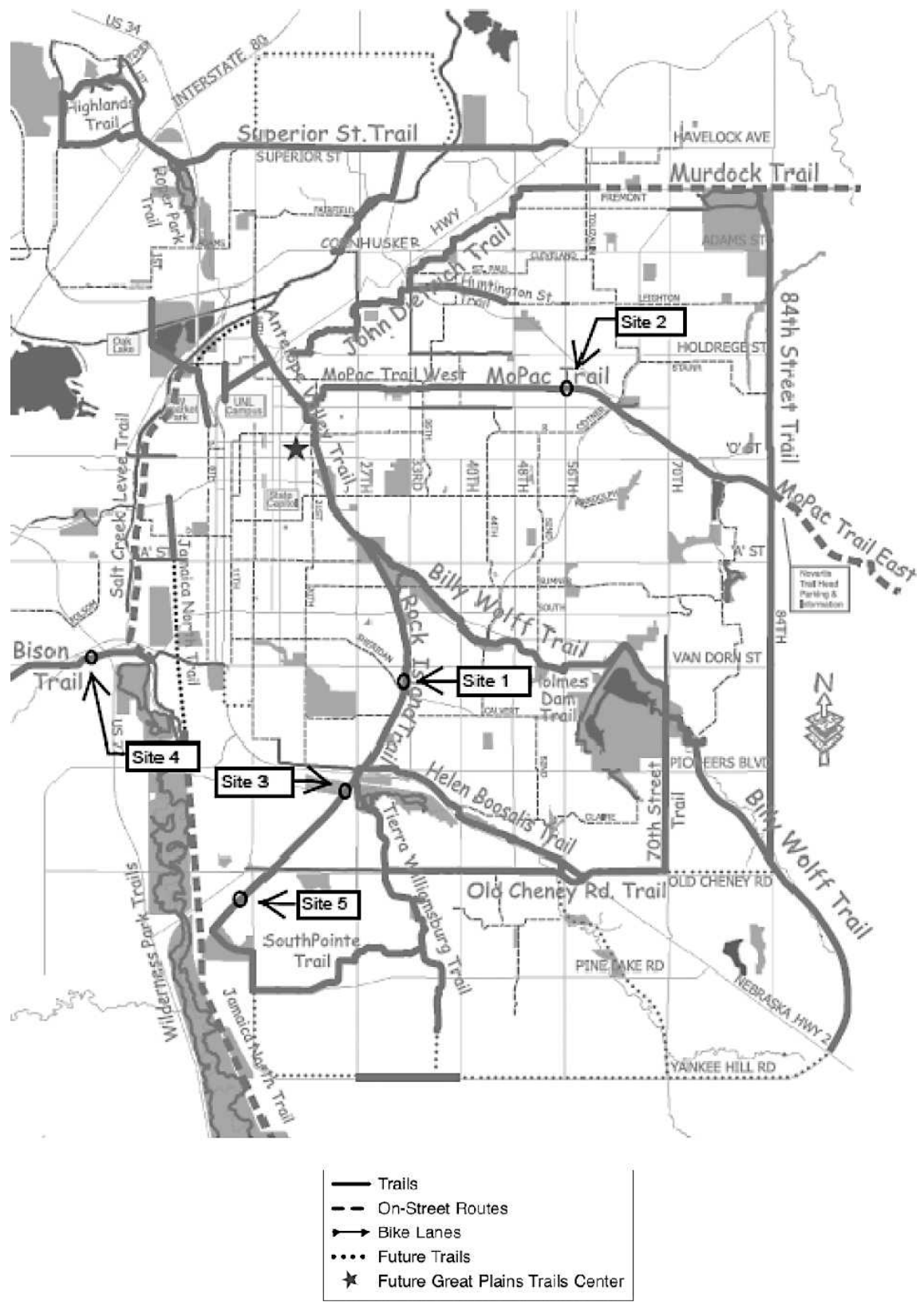

Fig. 1.-Locations of the five study sites within the city of Lincoln, Nebraska's urban recreational trail system. Map provided by Great Plains Trail Network 


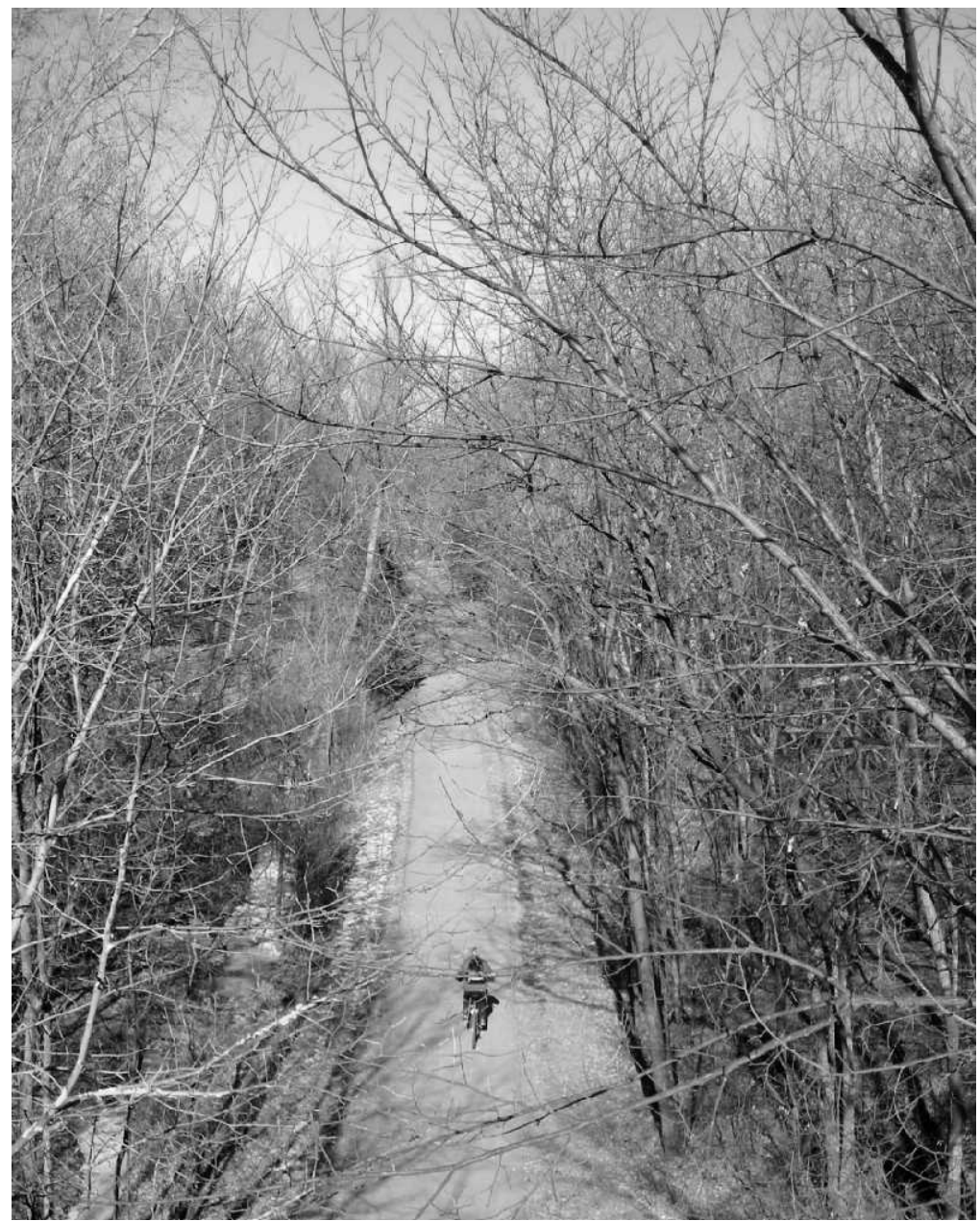

FIG. 2.-One of five urban forest corridors sampled along a bike trail in Lincoln, Nebraska

and Siberian elm (Ulmus pumila); however, a few samples could not be identified to species. The non-native, low-growing shrub wintercreeper (Euonymus fortunei) was observed in sites 1 , 2 and 3 but was not recorded in the samples.

For each tree species, the size of the individual with the largest diameter at each site was used to indicate how recently the species had established at the site (Table 4). Because the relationship between tree diameter and age varies with environmental conditions (Iakovoglou et al., 2001), this information was used as a general indicator of the relative age of the tree. The five largest trees at the sites consisted mostly of native species, but elm was the second largest tree at sites 2 and 4, indicating it is a relatively older invader at these sites. The smaller diameters of the other non-native species indicate they are comparatively more recent invaders of the forest corridors.

Native species did not differ greatly in species richness among points from the assumed source patch to the end of the corridor (Table 5). Non-native species richness did not 
TABLE 1.-Site information for the five segments of bike trail sampled in Lincoln, Nebraska. Each sampling point was located midway across the width of each forest corridor

\begin{tabular}{|c|c|c|c|c|c|}
\hline \multirow[b]{3}{*}{ Date sampled } & \multicolumn{5}{|c|}{ Site } \\
\hline & 1 & 2 & 3 & 4 & 5 \\
\hline & $3 / 13 / 08$ & $3 / 20 / 08$ & $3 / 27 / 08$ & $4 / 4 / 08$ & $4 / 4 / 08$ \\
\hline $\begin{array}{l}\text { Number of points } \\
\text { sampled }\end{array}$ & 14 & 13 & 19 & 10 & 17 \\
\hline $\begin{array}{l}\text { Number of points part } \\
\text { of pair on opposite } \\
\text { sides of trail }\end{array}$ & 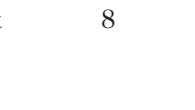 & 0 & 18 & 0 & 14 \\
\hline $\begin{array}{l}\text { Number of points on } \\
\text { one side of trail }\end{array}$ & 6 & 13 & 1 & 10 & 3 \\
\hline $\begin{array}{l}\text { Length of forest } \\
\text { sampled }\end{array}$ & $365 \mathrm{~m}$ & $470 \mathrm{~m}$ & $370 \mathrm{~m}$ & $435 \mathrm{~m}$ & $450 \mathrm{~m}$ \\
\hline $\begin{array}{l}\text { Width of forest } \\
\text { sampled }\end{array}$ & $25-50 \mathrm{~m}$ & $30 \mathrm{~m}$ & $40-65 \mathrm{~m}$ & $35-50 \mathrm{~m}$ & $12-15 \mathrm{~m}$ \\
\hline $\begin{array}{l}\text { Year trail segment } \\
\text { built }\end{array}$ & 1990 & 1992 & 1997 & 2002 & 2004 \\
\hline Site history & $\begin{array}{l}\text { Abandoned } \\
\text { railroad bed }\end{array}$ & $\begin{array}{l}\text { Abandoned } \\
\text { railroad bed }\end{array}$ & $\begin{array}{l}\text { Abandoned } \\
\text { railroad bed }\end{array}$ & Levee & $\begin{array}{l}\text { Abandoned } \\
\text { railroad bed }\end{array}$ \\
\hline
\end{tabular}

decrease significantly along the corridor with distance to source (Table 5, Fig. 3). There was no significant corridor effect for total species richness or total native species richness. For individual woody species, common buckthorn and honeysuckle displayed a significant corridor effect, decreasing significantly in abundance as distance from the source patch increased (Table 5; $\mathrm{P}=0.031$ and 0.030 , respectively).

\section{Discussion}

Urban forests develop from the survival of remnant trees, the planting of commerciallyraised trees from nurseries and from the unmanaged reproduction of native and non-native trees (McBride and Jacobs, 1976). The predominance of native trees in our study suggests the urban forest corridors we sampled may have developed from remnant native trees that were historically present along creeks in the Lincoln floodplain. For example, boxelder, green ash, hackberry, honey locust and black walnut are typical of native floodplain forests in eastern Nebraska (Weaver, 1960). In the absence of fire, these species may have expanded their populations in the Lincoln Park system.

However, some of these native species may consist of escaped cultivars that have been planted by the City of Lincoln's Parks and Recreation Department. The department's list of approved tree species for city streets includes cultivars of honeylocust and hackberry, as well as native strains of Kentucky coffeetree (City of Lincoln, 2010). None of five non-native species recorded in our study is currently listed as an approved tree, although they may have been planted in the past. Private residences are a likely source for the non-native species recorded in our study. Because the non-native species in our study are absent from Nebraska's noxious weed list, homeowners are allowed to use these species in landscaping. At least one local nursery still carries common buckthorn. Although white mulberry and tree-of-heaven are not readily available from local nurseries, they may have been sold in the past or homeowners may have obtained these species from other sources. 
TABLE 2.- Tree and shrub species recorded at five forest corridors along bike trails in Lincoln, Nebraska in Mar. and Apr. 2008. Species marked with an asterisk (*) are non-native

\begin{tabular}{|c|c|c|c|}
\hline Scientific name & Common name & $\begin{array}{l}\text { Number of sites } \\
\text { present }(n=5)\end{array}$ & $\begin{array}{l}\text { Number of points } \\
\text { present }(\mathrm{n}=73)\end{array}$ \\
\hline Celtis occidentalis & Hackberry & 5 & 42 \\
\hline Fraxinus spp. & Ash spp. & 5 & 21 \\
\hline Ulmus spp.* & Elm spp. & 4 & 19 \\
\hline Prunus spp. & Plum spp. & 4 & 11 \\
\hline Morus alba* & White mulberry & 4 & 9 \\
\hline Acer negundo & Boxelder & 3 & 13 \\
\hline Acer saccharum & Silver maple & 3 & 4 \\
\hline Lonicera spp.* & Honeysuckle & 3 & 7 \\
\hline Prunus spp. & Cherry spp. & 3 & 6 \\
\hline Gleditsia triacanthos & Honey locust & 3 & 4 \\
\hline Sambucus canadensis & Elderberry & 3 & 4 \\
\hline Rhamnus cathartica* & Common buckthorn & 2 & 6 \\
\hline Populus deltoides & Cottonwood & 1 & 8 \\
\hline Rhus glabra & Smooth sumac & 1 & 5 \\
\hline Juglans nigra & Walnut & 1 & 2 \\
\hline Ailanthus altissima* & Tree-of-heaven & 1 & 2 \\
\hline Toxicodendron radicans & Poison ivy & 1 & 1 \\
\hline Juniperus virginiana & Red cedar & 1 & 1 \\
\hline Gymnocladus dioica & Kentucky coffeetree & 1 & 1 \\
\hline
\end{tabular}

Of the non-native species sampled, white mulberry was the most commonly encountered. In Nebraska, white mulberry is weedy and one of the most abundant trees (Kaul et al., 2006). Because birds devour the fruits of white mulberry and spread the seeds, it is often abundant along forest edges and fencerows (Kaul et al., 2006).

Like white mulberry, common buckthorn is spread by fruit-eating birds (Schierenbeck, 2004; Knight et al., 2007). The high nitrogen concentration of buckthorn litter alters nutrient and carbon cycling within ecosystems and may lead to the decline of native species, although this has not been quantified (Knight et al., 2007). The conditions preferred by buckthorn were present along the bike trails, as buckthorn has an affinity for disturbed areas and can grow quickly in open conditions (Knight et al., 2007). These conditions are also appropriate for tree-of-heaven, which tolerates a wide range of soils and is common in disturbed urban areas (Kaufman and Kaufman, 2007).

Although the non-native species sampled in this study were not among the most dominant species, their presence along the bike trails indicates they have the potential to spread along these corridors. Because woody plants have a long life span and take a long time to reach reproductive age, there can be significant lag periods over the course of a woody plant invasion (Wangen and Webster, 2006). The relatively younger age (smaller size) of non-native species along corridors in Lincoln, suggest that over time their representation in the urban forest will increase. The representation of non-native species in urban vegetation is increasing worldwide (Kowarik, 2008). The species that are dispersed by fruit-eating birds, white mulberry and common buckthorn, may become particularly successful invaders. In the New York metropolitan area, species that were deciduous, shrubs or vines with fleshy fruit were the most successful in increasing their distribution (Aronson $e t$ $a l ., 2007)$. The corridor effect detected for common buckthorn is likely due to vertebratedispersed seeds, which travel less than $50 \mathrm{~m}$ (Willson, 1993) and new plants may therefore 


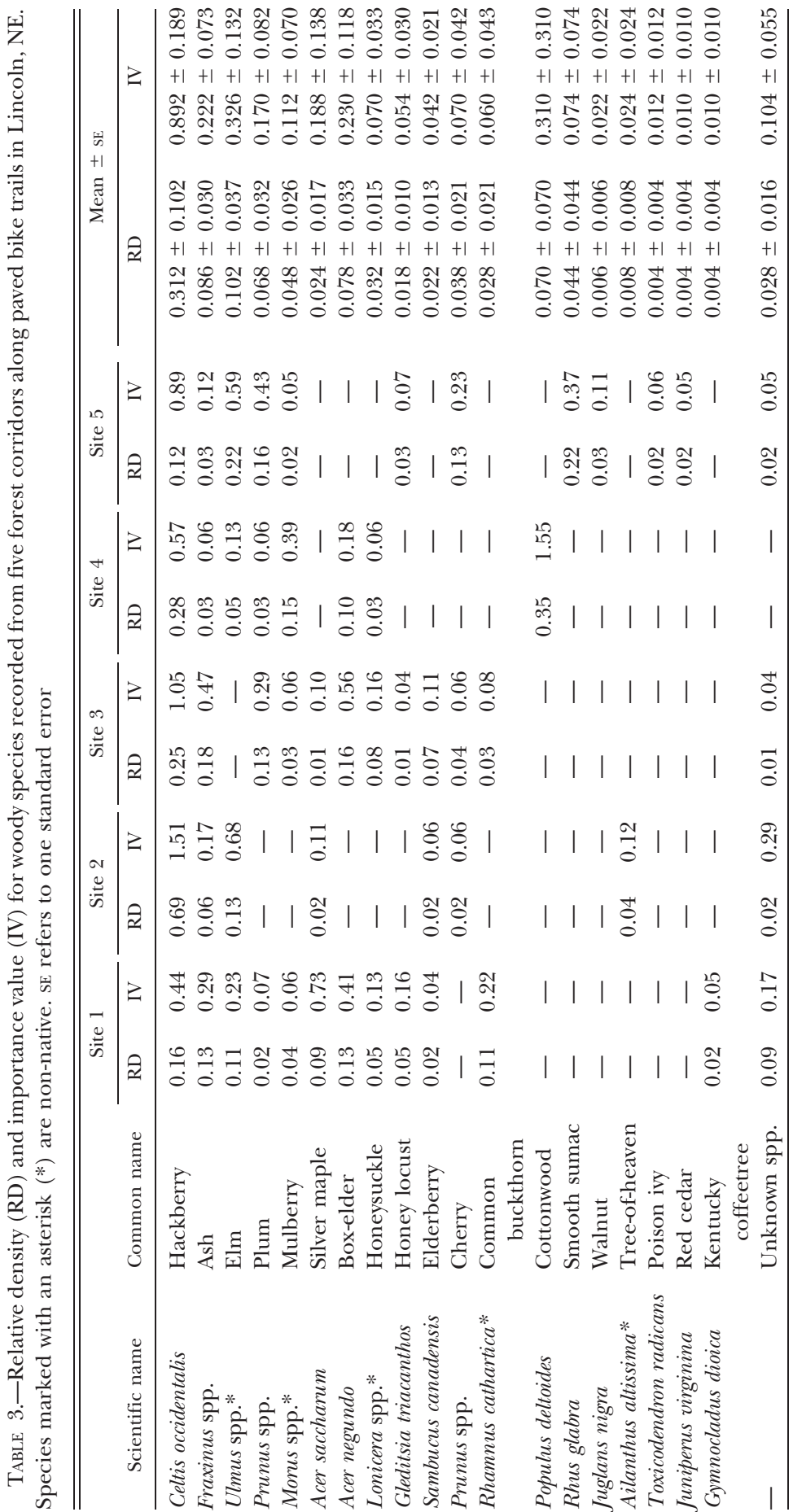


TABLE 4.- Size of tree with largest diameter $(\mathrm{cm})$ for each species at each site. Species marked with an asterisk $(*)$ are non-native

\begin{tabular}{llccccc}
\hline \hline \multicolumn{1}{c}{ Scientific name } & \multicolumn{1}{c}{ Common name } & Site 1 & Site 2 & Site 3 & Site 4 & Site 5 \\
\hline Populus deltoides & Cottonwood & - & - & - & - & 71.4 \\
Celtis occidentalis & Hackberry & 18.4 & 37.2 & 62.6 & 43.2 & 24.5 \\
Acer saccharum & Silver maple & 39.4 & 23.8 & 21.0 & - & - \\
Acer negundo & Box-elder & 21.9 & - & 29.9 & - & 12.7 \\
Ulmus spp.* & Elm & 7.0 & 31.1 & - & 18.4 & 5.1 \\
Prunus spp. & Plum & 12.4 & - & 15.2 & 16.2 & 0.5 \\
Ailanthus altissima* & Tree-of-heaven & - & 8.9 & - & - & - \\
Morus alba* & White mulberry & 1.0 & - & 15.0 & 4.1 & 12.1 \\
Fraxinus spp. & Ash & 19.1 & 4.4 & 2.9 & 8.4 & 0.6 \\
Toxicodendron radicans & Poison ivy & - & - & - & - & 7.0 \\
Gleditsia triacanthos & Honey locust & 12.7 & - & 4.4 & 2.5 & - \\
Juglans nigra & Walnut & - & - & - & - & 5.4 \\
Rhamnus cathartica & Common buckthorn & 4.8 & - & 3.5 & 4.2 & - \\
Rhus glabra & Smooth sumac & - & - & - & 2.86 & - \\
Lonicera spp.* & Honeysuckle & 1.6 & - & 6.1 & - & 0.4 \\
Gymnocladus dioica & Kentucky coffeetree & 2.4 & - & - & - & - \\
Sambucus canadensis & Elderberry & 0.9 & 3.0 & 1.3 & - & - \\
Prunus spp. & Cherry & - & 1.4 & 0.9 & 2.9 & - \\
Juniperus virginiana & Red cedar & - & - & - & 0.13 & - \\
\hline
\end{tabular}

be clustered towards the presumed source of the invasion in the source patch. The majority of species sampled may have not displayed a corridor effect because corridors may act as edges and intercept propagules from the adjacent suburban landscape matrix (With, 2002). In addition, seed predation has been observed to increase with forest fragmentation in some studies (Holl and Lulow, 1997; Ness and Morin, 2008), which could counteract increased seed dispersal by vertebrates along forest edges. However, studies have also shown no correlation between seed predation rates and degree of fragmentation (Holl and Lulow, 1997; Farwig et al., 2008) so it is difficult to discern the role seed predation may play in shaping the composition of tree species in these urban forest corridors.

\section{ConCLuSions}

Because urban areas receive more intentional and accidental introductions than areas with less human influence, they are particularly vulnerable to invasions by non-native plant species (Kowarik, 1995). Non-native woody plant species, including those recorded in this study, can impact ecosystem processes and community structure in forests by altering nutrient cycling, increasing litter decomposition rates, reducing the abundance of native plant species and reducing nest success (Schmidt and Whelan, 1999; Borgmann and Rodewald, 2004; Knight et al., 2007). Therefore land managers should strive to reduce the abundance of non-native species in urban forests if they want to maintain a high biodiversity of native species (Dearborn and Kark, 2010). Landscaping is one major pathway for the spread of non-native plant species in urban areas (Allen et al., 2006) and the public should be educated about the negative impacts of non-native species (Reichard and White, 2001).

In addition, volunteer groups could be used to remove non-native species that are observed growing along urban trails. The City of Lincoln has used volunteer groups in the past for cutting buckthorn growing in natural areas (T. Genrich, City of Lincoln, pers. 
TABLE 5.-Linear regression results for effect of distance along corridor on abundance of each species recorded at all five sites at each distance along the corridor. $B$ is the coefficient of the regression, $\mathrm{SE}$ is the standard error of the regression coefficient. Species marked with an asterisk (*) are non-native

\begin{tabular}{|c|c|c|c|c|c|c|}
\hline Scientific name & Variable & $B$ & $\mathrm{SE}$ & $F_{(1,8)}$ & $r^{2}$ & $P$ \\
\hline \multirow[t]{2}{*}{ Celtis occidentalis } & Distance & 0.01424 & 0.00884 & 2.59 & 0.245 & 0.146 \\
\hline & Intercept & 4.227 & 1.416 & & & \\
\hline \multirow[t]{2}{*}{ Fraxinus spp. } & Distance & 1.80000 & 0.50617 & 0.12 & 0.0152 & 0.7342 \\
\hline & Intercept & -0.00111 & 0.00316 & & & \\
\hline \multirow[t]{2}{*}{ Ulmus spp.* } & Distance & -0.00364 & 0.00607 & 0.36 & 0.0429 & 0.566 \\
\hline & Intercept & 2.391 & 0.973 & & & \\
\hline \multirow[t]{2}{*}{ Prunus spp. } & Distance & -0.00404 & 0.00475 & 0.72 & 0.0830 & 0.419 \\
\hline & Intercept & 1.745 & 0.760 & & & \\
\hline \multirow{2}{*}{ Morus alba* } & Distance & 0.00424 & 0.00306 & 1.92 & 0.194 & 0.203 \\
\hline & Intercept & 0.327 & 0.490 & & & \\
\hline \multirow[t]{2}{*}{ Acer saccharum } & Distance & -0.000303 & 0.00266 & 0.01 & 0.00161 & 0.912 \\
\hline & Intercept & 0.491 & 0.427 & & & \\
\hline \multirow[t]{2}{*}{ Acer negundo } & Distance & -0.00646 & 0.00662 & 0.95 & 0.107 & 0.357 \\
\hline & Intercept & 2.573 & 1.060 & & & \\
\hline \multirow[t]{2}{*}{ Lonicera spp.* } & Distance & -0.00434 & 0.00165 & 6.90 & 0.463 & 0.030 \\
\hline & Constant & 1.236 & 0.265 & & & \\
\hline \multirow[t]{2}{*}{ Prunus spp. } & Distance & 0.00424 & 0.00551 & 0.59 & 0.0689 & 0.464 \\
\hline & Intercept & 0.32727 & 0.88319 & & & \\
\hline \multirow[t]{2}{*}{ Gleditsia triacanthos } & Distance & 0.00434 & 0.00218 & 3.97 & 0.332 & 0.082 \\
\hline & Intercept & -0.136 & 0.349 & & & \\
\hline \multirow[t]{2}{*}{ Sambucus canadensis } & Distance & 0.00060606 & 0.00220 & 0.08 & 0.0094 & 0.790 \\
\hline & Intercept & 0.31818 & 0.35221 & & & \\
\hline \multirow[t]{2}{*}{ Rhamnus cathartica* } & Distance & -0.00343 & 0.00131 & 6.84 & 0.461 & 0.031 \\
\hline & Intercept & 0.864 & 0.210 & & & \\
\hline \multirow[t]{2}{*}{ Populus deltoides } & Distance & -0.00566 & 0.00411 & 1.90 & 0.192 & 0.206 \\
\hline & Intercept & 2.164 & 0.658 & & & \\
\hline \multirow[t]{2}{*}{ Rhus glabra } & Distance & 0.00798 & 0.00535 & 2.23 & 0.218 & 0.174 \\
\hline & Intercept & -0.127 & 0.857 & & & \\
\hline \multirow[t]{2}{*}{ Juglans nigra } & Distance & -0.000202 & 0.000818 & 0.06 & 0.0076 & 0.811 \\
\hline & Intercept & 0.127 & 0.131 & & & \\
\hline \multirow[t]{2}{*}{ Ailanthus altissima* } & Distance & 0.000808 & 0.00162 & 0.25 & 0.0303 & 0.631 \\
\hline & Intercept & 0.09091 & 0.25884 & & & \\
\hline \multirow[t]{2}{*}{ Toxicodendron radicans } & Distance & -0.000505 & 0.000589 & 0.74 & 0.0842 & 0.416 \\
\hline & Intercept & 0.118 & 0.0943 & & & \\
\hline \multirow[t]{2}{*}{ Juniperus virginiana } & Distance & 0.000101 & 0.000614 & 0.03 & 0.0034 & 0.873 \\
\hline & Intercept & 0.03636 & 0.09840 & & & \\
\hline \multirow[t]{2}{*}{ Gymnocladus dioica } & Distance & -0.000909 & 0.0052486 & 3.000 & 0.273 & 0.122 \\
\hline & Intercept & 0.173 & 0.0841 & & & \\
\hline \multirow[t]{2}{*}{ Total species richness } & Distance & -0.00929 & 0.00756 & 1.51 & 0.159 & 0.254 \\
\hline & Intercept & 10.855 & 1.211 & & & \\
\hline \multirow[t]{2}{*}{ Native species richness } & Distance & -0.00162 & 0.00475 & 0.12 & 0.0143 & 0.743 \\
\hline & Intercept & 7.018 & 0.761 & & & \\
\hline Non-native species richness & Distance & -0.00768 & 0.00506 & 2.30 & 0.223 & 0.168 \\
\hline & Intercept & 3.836 & 0.811 & & & \\
\hline Native species abundance & Distance & 0.00636 & 0.00618 & 1.06 & 0.117 & 0.334 \\
\hline & Intercept & 15.0909 & 0.990 & & & \\
\hline Non-native species & Distance & -0.00636 & 0.00618 & 1.06 & 0.117 & 0.334 \\
\hline abundance & Intercept & 4.909 & 0.990 & & & \\
\hline
\end{tabular}




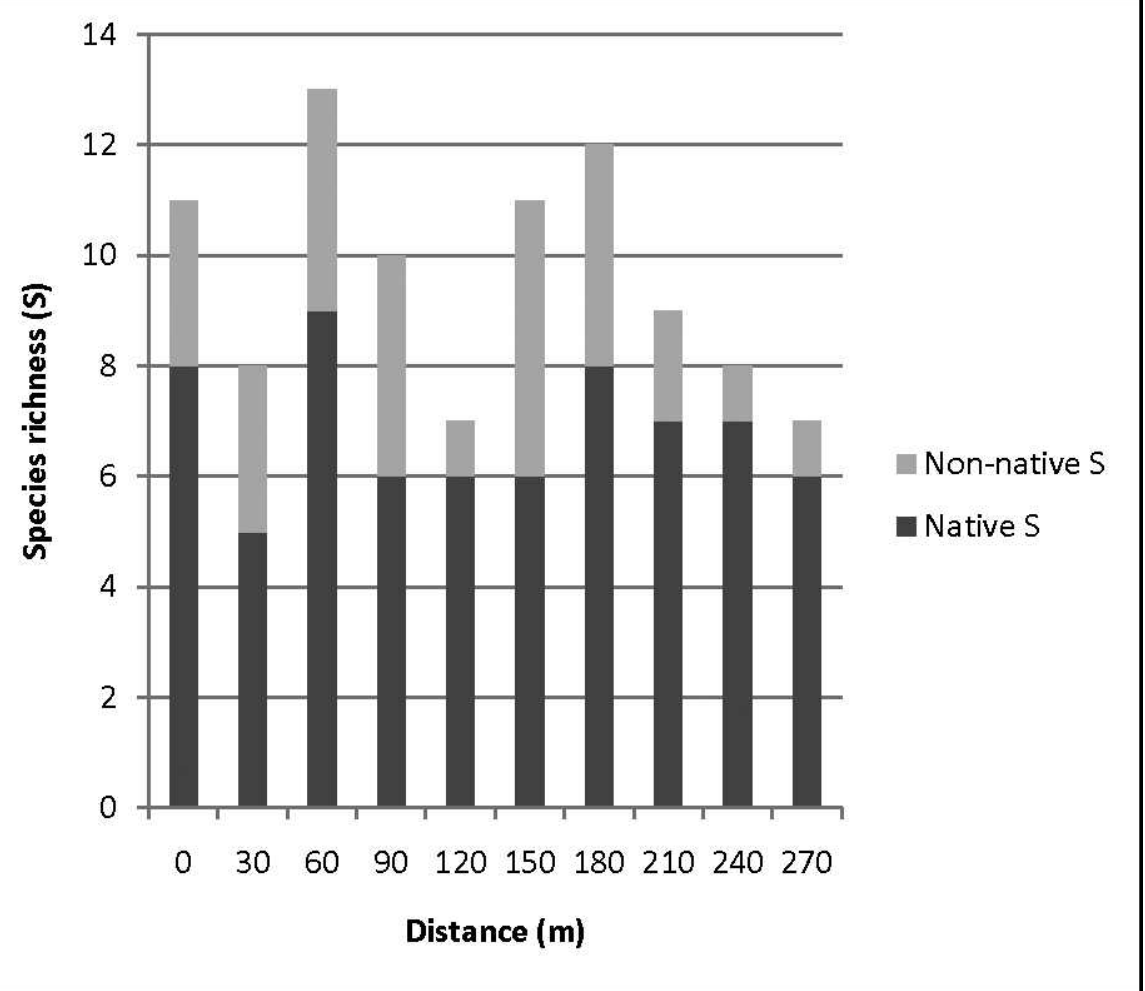

Fig. 3.-Native species richness and non-native species richness recorded at $30 \mathrm{~m}$ intervals along the corridor at all five sites

comm.) and could use the same approach for removing non-native vegetation along trails. Although labor intensive, removing individual plants of non-native species before they have become abundant and have caused major changes to the local ecosystem offers the best chances for preserving biodiversity in the long run (Zavaleta et al., 2001; Webster et al., 2006). Complete eradication is likely unrealistic, particularly if the trails serve as corridors for the dispersal of non-native propagules, and repeated removal efforts may be needed to reduce the regeneration of non-native species (D'Antonio and Meyerson, 2002; Vidra et al., 2007; Heneghan et al., 2009). Because removal of non-native species often disturbs the soil and encourages the growth of non-native species adapted to disturbance, native species should be planted to replace any plants that are removed (D'Antonio and Meyerson, 2002; Vidra et al., 2007; McGlone et al., 2009). Replanting may reduce the need for subsequent non-native species removal as the native species occupy space and use resources, making invasion by other species more difficult (Shea and Chesson, 2002).

Acknowledgments. - The Nebraska Cooperative Fish and Wildlife Research Unit is jointly supported by a cooperative agreement between the United States Geological Survey, the Nebraska Game and Parks Commission, the University of Nebraska-Lincoln, the United States Fish and Wildlife Service and the Wildlife Management Institute. We would like to thank Rich Lodes of the Nebraska Forest Service for help with woody plant identification. An earlier version of the manuscript was improved by comments by Katie Reed and Tom Powers. 


\section{Literature Cited}

Alberti, M. ANd J. M. Marzluff. 2004. Ecological resilience in urban ecosystems: linking urban patterns to human and ecological functions. Urban Ecosyst., 7:241-265.

Allen, C. R., A. S. Garmestani, J. A. Labram, A. E. Peck and L. B. Prevost. 2006. When landscaping goes bad: the incipient invasion of Mahonia bealei in the Southeastern United States. Biol. Invas., 8:169-176.

Aronson, M. F. J., S. N. Handel and S. E. Clemants. 2007. Fruit type, life form and origin determine the success of woody plant invaders in an urban landscape. Biol. Invas., 9:465-475.

Ashton, I. W., L. A. Hyatt, K. M. Howe, J. Gurevitch and M. T. Lerdau. 2005. Invasive species accelerate decomposition and litter nitrogen loss in a mixed deciduous forest. Ecol. Appl., 15:1263-1272.

Bas, J. M., P. Pons And C. Gomez. 2006. Exclusive frugivory and seed dispersal of Rhamnus alternus in the bird breeding season. Plant Ecol., 183:77-89.

Benninger-Truax, M., J. L. Vankat and R. L. Schaefer. 1992. Trail corridors as habitat and conduits for movement of plant species in Rocky Mountain National Park, Colorado, USA. Landscape Ecol., 6:269-278.

Bohlen, P. J., S. Scheu, C. M. Hale, M. A. Mglean, S. Migge, P. M. Groffman and D. Parkinson. 2004. Nonnative invasive earthworms as agents of change in northern temperate forests. Front. Ecol. Environ., 2:427-435.

Bolund, P. and S. Hunhammar. 1999. Ecosystem services in urban areas. Ecol. Econ., 29:293-301.

Borgmann, K. L. AND A. D. Rodewald. 2004. Nest predation in an urbanizing landscape: the role of exotic shrubs. Ecol. Appl., 14:1757-1765.

Braithwaite, R. W., W. M. Lonsdale and J. A. Estbergs. 1989. Alien vegetation and native biota in tropical Australia: the impact of Mimosa pigra. Biol. Conserv., 48:189-210.

Brower, J. E., J. H. Zar and C. N. Von Ende. 1997. Field and laboratory methods for general ecology. McGraw-Hill, New York, U.S.A. 288 p.

Brown, L. E., L. Quandt, S. Scheinost, J. Wilson and D. Witte. 1980. Soil survey of Lancaster County, Nebraska. U.S. Department of Agriculture, Soil Conservation Service, in cooperation with University of Nebraska, Conservation and Survey Division. $174 \mathrm{p}$.

Burgess, J. L. and E. L. Worthen. 1916. Soil survey of Lancaster County, Nebraska, p. 1-15. In: A. J. Sawyer (ed.). Lincoln, the Capital City and Lancaster County, Nebraska, Volume 1. The S.J. Clarke Publishing Company, Chicago, Illinois, U.S.A. 358 p.

Chace, J. F. And J. J. Walsh. 2006. Urban effects on native avifauna: a review. Landscape Urban Plan., 74:46-69.

Chen, W. Y. And C. Y. Jim. 2008. Assessment and valuation of the ecosystem services provided by urban forests, p. 53-83. In: M. M. Carreiro, Y-C. Song and J. Wu (eds.). Ecology, Planning, and Management of Urban Forests: International Perspectives. Springer, New York, New York, U.S.A. 468 p.

Christen, D. and G. Matlack. 2006. The role of roadsides in plant invasions: a demographic approach. Conserv. Biol., 20:385-391.

City of Lincoln. 1992. State of the trails report. Recreational Trails Advisory Committee. 15 p. 2010. Approved trees for streets. City of Lincoln, Nebraska Parks and Recreation Department. http://lancaster.ne.gov/city/parks/communityforestry/trees.htm [Accessed Jun. 14, 2010]

Collier, M. H., J. L. Vankat and M. R. Hughes. 2002. Diminished plant richness and abundance below Lonicera maackii, an invasive shrub. Am. Midl. Nat., 147:60-71.

Coluinge, S. K. 1996. Ecological consequences of habitat fragmentation: implications for landscape architecture and planning. Landscape Urban Plan., 36:59-77.

Copple, N. 1959. Tower on the plains: Lincoln's centennial history 1859-1959. Jacob North, Inc., Lincoln, Nebraska, U.S.A. 228 p.

D’Antonio, G. and L. A. Meyerson. 2002. Exotic plant species as problems and solutions in ecological restoration: a synthesis. Restor. Ecol., 10:703-713.

Dearborn, D. C. and S. Kark. 2010. Motivations for conserving urban biodiversity. Conserv. Biol., 24:432-440. 
Dickens, S. M., F. Gerhardt and S. K. Collinge. 2005. Recreational portage trails as corridors facilitating non-native plant invasions of the Boundary Waters Canoe Area Wilderness (U.S.A.). Conserv. Biol., 19:1653-1657.

Dukes, J. S. And H. A. Mooney. 1999. Does global change increase the success of biological invaders? Trends Ecol. Evol., 14:135-139.

Ehrenfeld, J. G., P. Kourtev and W. Huang. 2001. Changes in soil functions following invasions of exotic understory plants in deciduous forests. Ecol. Appl., 11:1287-1300.

FAGAN, M. E. And D. R. PEART. 2004. Impact of the invasive shrub glossy buckthorn (Rhamnus frangula L.) recruitment by canopy trees. For. Ecol. Manage., 194:95-107.

Farwig, N., B. Bleher, S. Von Der Gonna and K. Bohning-Gaese. 2008. Does forest fragmentation and selective logging affect seed predators and seed predation rates of Prunus africana (Rosaceae)? Biotropica, 40:218-224.

Flory, S. L. ANd K. Clay. 2009. Effects of road and forest successional age on experimental plant invasions. Biol. Conserv., 142:2531-2537.

Forman, R., D. Sperling, J. Bissonette, A. Clevenger, C. Cutshall, V. Dale, L. Fahrig, R. France, C. Goldman, K. Heanue, J. Jones, F. Swanson, T. Turrentine and T. Winter. 2003. Road ecology: science and solutions. Island Press, Covelo, California, U.S.A. 504 p.

Galbraith-Kent, S. L. and S. N. Handel. 2008. Invasive Acer platanoides inhibits native sapling growth in forest understorey communities. J. Ecol, 96:293-302.

Great Plains Trail Network. 2010. Great Plains Trails Network webpage http://www.gptn.org/ [Accessed Jun. 14, 2010]

Gundale, M. J. 2002. Influence of exotic earthworms on the soil horizon and the rare fern Botrychium mormo. Conserv. Biol., 16:1555-1561.

Gurevitch, J., T. G. Howard, I. W. Ashton, E. A. Leger, K. M. Howe, E. Woo and M. Lerdau. 2008. Effects of experimental manipulation of light and nutrients on establishment of seedlings or native and invasive species in Long Island, NY forests. Biol. Invasions, 10:821-831.

Heneghan, L., J. Steffen and K. Fagen. 2007. Interactions of an introduced shrub and introduced earthworms in an Illinois urban woodland: impact on leaf litter decomposition. Pedobiologia, 50:543-551.

- L. Umek, B. Bernau, K. Grady, J. Iatropulos, D. Jabon and M. Workman. 2009. Ecological research can augment restoration practice in urban areas degraded by invasive species - examples from Chicago Wilderness. Urban Ecosyst., 12:63-77.

High Plains Regional Climate Center. 2010. Lincoln, Nebraska weather and climate facts http://www. hprcc.unl.edu/nebraska/Lincolnclimate-facts.html [Accessed Jun. 1, 2010]

Hobbs, R. J. And L. F. Huenneke. 1992. Disturbance, diversity, and invasion: implications for conservation. Conserv. Biol., 6:324-337.

- , S. Arico, J. Aronson, J. S. Baron, P. Bridgewater, V. A. Cramer, P. R. Epstein, J. J. Ewel, C. A. Klink, A. E. Lugo, D. Norton, D. Ojima, D. M. Richardson, E. W. Sanderson, F. Valladares, M. Vila, R. Zamora and M. Zobel. 2006. Novel ecosystems: theoretical and management aspects of the new ecological world order. Glob. Ecol. Biogeog., 15:1-7.

Holl, K. D. And M. E. Lulow. 1997. Effects of species, habitat, and distance from edge on post-dispersal seed predation in a tropical rainforest. Biotropica, 29:459-468.

Honnay, O., K. Verheyen and M. Hermy. 2002. Permeability of ancient forest edges for weedy plant species invasion. Forest. Ecol. Manage., 161:109-122.

Iakovoglou, V., J. Thompson, L. Burras and R. Kipper. 2001. Factors related to tree growth across urbanrural gradients in the Midwest, USA. Urban Ecosyst., 5:71-85.

Kaufman, S. R. And W. Kaufman. 2007. Invasive plants: a guide to identification, impacts, and control of common North American species. Stackpole Books, Mechanicsburg, Pennsylvania, U.S.A. 458 p.

Kaul, R. B., D. M. Sutherland and S. B. Rolfsmeier. 2006. The flora of Nebraska. University of Nebraska Press, Lincoln, Nebraska, U.S.A. 966 p.

Knight, K. S., J. S. Kurylo, A. G. Endress, J. R. Stewart and P. B. Reich. 2007. Ecology and ecosystem impacts of common buckthorn (Rhamnus cathartica): a review. Biol. Invas., 9:925-937. 
Kourtev, P. S., J. G. Ehrenfeld and W. Z. Huang. 1998. Effects of exotic plant species on soil properties in hardwood forests of New Jersey. Water Air Soil Poll., 105:493-501.

, W. Z. Huang and J. G. Ehrenfeld. 1999. Differences in earthworm densities and nitrogen dynamics in soils under exotic and native plant species. Biol. Invasions, 1:237-245.

KowariK, I. 1995. On the role of alien species in urban flora and vegetation, p. 85-103. In: P. Pysek, K. Prach, M. Rejmanek and M. Wade (eds.). Plant invasions - general aspects and special problems. SPB Academic Publishing, Amsterdam, the Netherlands. 263 p.

2008. On the role of alien species in urban flora and vegetation, p. 321-338. In: J. M. Marzluff, E. Shulenberger, W. Endlicher, M. Alberti, G. Bradley, C. Ryan, U. Simon and C. ZumBrunnen (eds.). Urban ecology: an international perspective on the interaction between humans and nature. Springer, New York, New York, U.S.A. 807 p.

Lincoln Chamber of Commerce. 1923. Lincoln, Nebraska's Capital City, 1867-1923. Woodruff Printing Office, Lincoln, Nebraska, U.S.A. 191 p.

Martin, P. H. 1999. Norway maple (Acer platanoides) invasion of a natural forest stand: understory consequence and regeneration pattern. Biol. Invas., 1:215-222.

McBRide, J. ANd D. JaCobs. 1976. Urban forest development: a case study, Menlo Park, California. Urban Ecol., 2:1-14.

Mcdonnell, M. J. And S. T. A. Pickett. 1990. Ecosystem structure and function along urban-rural gradients: an unexploited opportunity for ecology. Ecology, 71:1232-1237.

MCglone, C. M., J. D. Springer AND D. C. Laughlin. 2009. Can pine forest regeneration promote a diverse and abundant understory and simultaneously resist nonnative invasion? Forest Ecol. Manage., 258:2638-2646.

Mcpherson, E. G., D. Nowak, G. Heisler, S. Grimmond, C. Souch, R. Grant and R. Rowntree. 1997. Quantifying urban forest structure, function, and value: the Chicago Urban Forest Climate Project. Urban Ecosyst., 1:49-61.

Miller, K. E. AND D. L. Gorchov. 2004. The invasive shrub, Lonicera maackii, reduces growth and fecundity of perennial forest herbs. Oecologia, 139:359-375.

Ness, J. H. AND D. F. Morin. 2008. Forest edges and landscape history shape interactions between plants, seed-dispersing ants and seed predators. Biol. Conserv., 141:838-847.

Pauchard, A. and P. B. Alaback. 2006. Edge type defines alien plant species invasions along Pinus contorta burned, highway and clearcut forest edges. For. Ecol. Manage., 223:327-335.

Potito, A. P. And S. W. BEAtty. 2005. Impacts of recreation trails on exotic and ruderal species distribution in grassland areas along the Colorado front range. Environ. Manage., 36: 230-236.

Reichard, S. H. ANd P. White. 2001. Horticulture as a pathway of invasive plant introductions in the United States. Bioscience, 51:103-113.

Savard, J-P. L., P. Clefrgau and G. Mennechez. 2000. Biodiversity concepts and urban ecosystems. Landscape Urban Plan., 48:131-142.

SCHIERENBECK, K. 2004. Japanese honeysuckle (Lonicera japonica) as an invasive species: history, ecology, and context. Crit. Rev. Plant Sci., 23:391-400.

Schmidt, K. A. and C. J. Whelan. 1999. Effects of exotic Lonicera and Rhamnus on songbird nest predation. Conserv. Biol., 13:1502-1506.

SEARns, R. M. 1995. The evolution of greenways as an adaptive urban landscape form. Landscape Urban Plan., 33:65-80.

ShEA, K. And P. Chesson. 2002. Community ecology theory as a framework for biological invasions. Trends Ecol. Evol., 17:170-176.

Shustack, D. P., A. D. Rodewald and T. A. Waite. 2009. Springtime in the city: exotic shrubs promote earlier green-up of urban forests. Biol. Invas., 11:1357-1371.

Vidra, R. L., T. H. Shear and T. R. Wentworth. 2006. Testing the paradigms of exotic Species invasion in urban riparian forests. Nat. Area J., 26:339-350.

— _ - AND J. M. STUCKY. 2007. Effects of vegetation removal on native understory recovery in an exotic-rich urban forest. J. Torrey Bot. Soc., 134:410-419. 
Vitousek, P. M., L. R. Walker, L. D. Whiteaker, D. Mueller-Dombois and P. A. Matson. 1987. MuellerDombois, D. Biological invasion by Myrica faya alters ecosystem development in Hawaii. Science, 238:802-804.

WALKER, L. R. AND S. D. SMith. 1997. Impacts of invasive plants on community and ecosystem properties, p. 69-86. In: J. O. Luken and J. W. Thieret (eds.). Assessment and management of plant invasions. Springer, New York, U.S.A. 324 p.

Wangen, S. R. And C. R. Webster. 2006. Potential for multiple lag phases during biotic invasions: reconstructing an invasion of the exotic tree Acer platanoides. J. Appl. Ecol., 43:258-268.

WEAVER, J. E. 1960. Flood plain vegetation of the central Missouri Valley and contacts of woodland with prairie. Ecol. Monogr., 30:37-64.

- 1965. Vegetation of Nebraska. University of Nebraska Press, Lincoln, Nebraska. 185 p.

Webster, C. R., M. A. Jenkins and S. Jose. 2006. Woody invaders and the challenges they pose to forest ecosystems in the eastern United States. J. Forest., 104:366-374.

Willson, W. M. F. 1993. Dispersal mode, seed shadows, and colonization patterns. Vegetatio, 107/ 108:261-280.

With, K. A. 2002. The landscape ecology of invasive spread. Conserv. Biol., 16:1192-1203.

Yates, E. D., D. F. Levia and C. L. Williams. 2004. Recruitment of three non-native invasive plants into a fragmented forest in southern Illinois. For. Ecol. Manage, 190:119-130.

Yurkonis, K. A., S. J. Meiners And B. E. WachHolder. 2005. Invasion impacts diversity through altered community dynamics. J. Ecol., 93:1053-1061.

Zavaleta, E. S., R. J. Hobbs and H. A. Mooney. 2001. Viewing invasive species removal in a wholeecosystem context. Trends Ecol. Evol., 16:454-459. 